Submittal 8/7/15

\title{
Mary Bartelme Park Methods Document
}

Prepared by:

Research Fellow: M. Elen Deming, Professor, University of Illinois, Urbana-Champaign Research Assistant: D. Scott Douglas, University of Illinois, Urbana-Champaign

Firm Liaison: Hana Ishikawa, Design Principal, Site Design Group, Ltd.

Overview of CSI: This investigation was conducted as part of the Landscape Architecture Foundation's 2015 Case Study Investigation (CSI) program. CSI matches faculty-student research teams with design practitioners to document the benefits of exemplary high-performing landscape projects. Teams develop methods to quantify environmental, economic and social benefits and produce Case Study Briefs for LAF's Landscape Performance Series. 


\section{Landscape Performance Benefits}

\section{ENVIRONMENTAL BENEFITS}

\section{Captures and infiltrates all runoff from up to a $100-\mathrm{yr}, 24-\mathrm{hr}$ rain event.}

\section{Method}

The stormwater management system for the 2.3-acre park was designed to contain all stormwater runoff from a 100-year storm event. At the time of the permitting of this project, the design 100-year storm in the Chicago area is a 24-hour storm that produces 5.712 inches of precipitation. All run-off from the entire park footprint is directed to a subsurface stormwater management containment system via a network of surface drains and underground pipes.

The central element of the containment system is a 14,700 sf underground infiltration bed that is a minimum of 1.5 feet thick. This area is filled with CA-7 stone, which averages $3 / 4$ " -1 " in size and is clean so it does not include any fines (smaller stones and/or dust). The water storage capacity in this type of system is provided by the void space between the pieces of aggregate. This containment system is located above native soils that allow 1.9 "'/hr. of water to percolate down into the soil to recharge the groundwater. The infiltration bed provides 64,500 gallons of storage capacity $(0.198$ acre feet), which, combined with the infiltration into the soil is able to contain the runoff from a 100-year storm event for the site.

While the drainage system is connected to the city's combined sewer system, the system does not typically release water into the sewer during smaller storm events when the soil percolation rate of 1.9 "/hr. exceeds the amount of rainfall. 


\subsection{Rate Control (Sheet 1 of 2)}

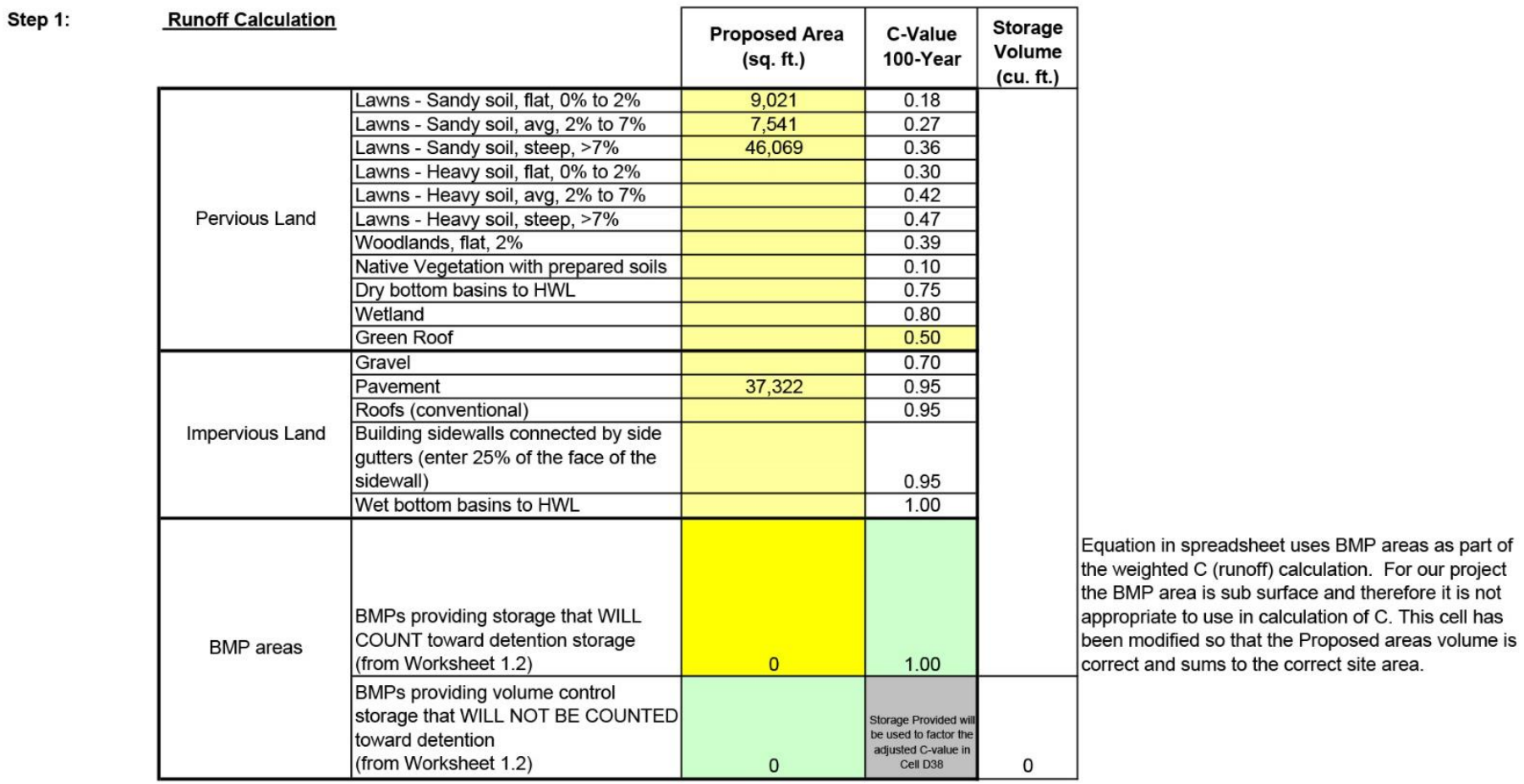

\begin{tabular}{|l|l|c|}
\hline \multirow{4}{*}{ Summary } & Total pervious area $(\mathrm{sq} \mathrm{ft})$ & 62,631 \\
\cline { 2 - 3 } & Total impervious area (sq ft) & 37,322 \\
\cline { 2 - 3 } & Total BMP area (sq ft) & 0 \\
\cline { 2 - 3 } & Total site area (sq ft) & 09,953 \\
\cline { 2 - 3 } & Weighted C-value (non BMP areas) & 0.56 \\
\cline { 2 - 3 } & Adjusted C-value [accounts for BMPs) & 0.00 \\
\hline & Notes: & $\begin{array}{l}\text { Make note of any adjustments made for } \\
\text { purposes of detention calcs here (such as } \\
\text { removal of roof area that will discharge directly } \\
\text { to Waters) }\end{array}$ \\
\hline
\end{tabular}

\section{Excerpt from the City of Chicago stormwater spreadsheet prepared by TERRA Engineering}




\begin{tabular}{|c|c|c|c|c|c|c|c|c|}
\hline \multirow[b]{3}{*}{$\begin{array}{c}\text { Storm } \\
\text { Duration } \\
\text { (minute) }\end{array}$} & \multirow[b]{3}{*}{$\begin{array}{c}\text { Runoff } \\
\text { Coefficient } \\
\text { C }\end{array}$} & \multirow{2}{*}{$\begin{array}{c}\text { STORM EVENT }(5,10,25,50 \text { or } 100)= \\
100\end{array}$} & \multirow[b]{3}{*}{$\begin{array}{c}\text { Drainage } \\
\text { Area A } \\
\text { (acres) }\end{array}$} & \multirow{2}{*}{\multicolumn{2}{|c|}{ Allowable release rate }} & \multirow[b]{2}{*}{1.450} & \multirow[b]{2}{*}{ cfs } & \multirow[b]{3}{*}{ 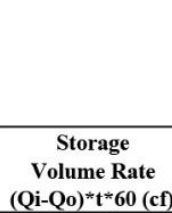 } \\
\hline & & & & & & & & \\
\hline & & $\begin{array}{c}\text { Rainfall } \\
\text { Intensity } \\
\text { (in/hr) } \\
\end{array}$ & & $\begin{array}{c}\text { Inflow } \\
\text { Rate } \\
\text { Q=CIA }\end{array}$ & \begin{tabular}{|c|} 
Total \\
Storm Vol \\
(cf) \\
\end{tabular} & $\begin{array}{c}\text { Release } \\
\text { Rate Qo } \\
\text { (cfs) }\end{array}$ & $\begin{array}{c}\text { Storage } \\
\text { Rate (Qi-Qo) } \\
\text { (cfs) } \\
\end{array}$ & \\
\hline 5 & 0.56 & 9.504 & 2.29 & 12.15 & 3,646 & 1.45 & 10.70 & 3,211 \\
\hline 10 & 0.56 & 7.792 & 2.29 & 9.96 & 5,978 & 1.45 & 8.51 & 5,108 \\
\hline 15 & 0.56 & 6.634 & 2.29 & 8.48 & 7,635 & 1.45 & 7.03 & 6,330 \\
\hline 20 & 0.56 & 5.795 & 2.29 & 7.41 & 8,893 & 1.45 & 5.96 & 7,153 \\
\hline 25 & 0.56 & 5.157 & 2.29 & 6.59 & 9,892 & 1.45 & 5.15 & 7,718 \\
\hline 30 & 0.56 & 4.655 & 2.29 & 5.95 & 10,714 & 1.45 & 4.50 & 8,104 \\
\hline 35 & 0.56 & 4.248 & 2.29 & 5.43 & 11,407 & 1.45 & 3.98 & 8,362 \\
\hline 40 & 0.56 & 3.911 & 2.29 & 5.00 & 12,003 & 1.45 & 3.55 & 8,524 \\
\hline 45 & 0.56 & 3.628 & 2.29 & 4.64 & 12,524 & 1.45 & 3.19 & 8,610 \\
\hline 50 & 0.56 & 3.385 & 2.29 & 4.33 & 12,986 & 1.45 & 2.88 & 8,637 \\
\hline 55 & 0.56 & 3.175 & 2.29 & 4.06 & 13,400 & 1.45 & 2.61 & 8,616 \\
\hline 60 & 0.56 & 2.992 & 2.29 & 3.83 & 13,774 & 1.45 & 2.38 & 8,555 \\
\hline 90 & 0.56 & 2.241 & 2.29 & 2.87 & 15,471 & 1.45 & 1.42 & 7,643 \\
\hline 120 & 0.56 & 1.806 & 2.29 & 2.31 & 16,630 & 1.45 & 0.86 & 6,193 \\
\hline 180 & 0.56 & 1.319 & 2.29 & 1.69 & 18,214 & 1.45 & 0.24 & 2,557 \\
\hline 240 & 0.56 & 1.049 & 2.29 & 1.34 & 19,313 & 1.45 & -0.11 & $-1,561$ \\
\hline 300 & 0.56 & 0.876 & 2.29 & 1.12 & 20,160 & 1.45 & -0.33 & $-5,934$ \\
\hline 360 & 0.56 & 0.755 & 2.29 & 0.97 & 20,850 & 1.45 & -0.48 & $-10,462$ \\
\hline 420 & 0.56 & 0.665 & 2.29 & 0.85 & 21,436 & 1.45 & -0.60 & $-15,095$ \\
\hline 480 & 0.56 & 0.596 & 2.29 & 0.76 & 21,945 & 1.45 & -0.69 & $-19,805$ \\
\hline 540 & 0.56 & 0.541 & 2.29 & 0.69 & 22,396 & 1.45 & -0.76 & $-24,573$ \\
\hline 600 & 0.56 & 0.495 & 2.29 & 0.63 & 22,801 & 1.45 & -0.82 & $-29,386$ \\
\hline 720 & 0.56 & 0.426 & 2.29 & 0.54 & 23,510 & 1.45 & -0.91 & $-39,115$ \\
\hline 1080 & 0.56 & 0.303 & 2.29 & 0.39 & 25,120 & 1.45 & -1.06 & $-68,817$ \\
\hline 1440 & 0.56 & 0.238 & 2.29 & 0.30 & 26,299 & 1.45 & -1.15 & $-98,950$ \\
\hline & & & & & & & $\begin{array}{l}\text { Required } \\
\text { Detention } \\
\text { Volume (cf) }\end{array}$ & 8,637 \\
\hline
\end{tabular}

Note: 1) the calculation assumes that the rising and recessing limb of inflow and outflow hydrograph are vertical

2) $1.450 \mathrm{cfs}$ is the allowable release rate plus infiltration rate $(Q=K A)$. See Geotechnical report test pit $B-2$.

Excerpt from the City of Chicago stormwater spreadsheet prepared by TERRA Engineering

Infiltration bed dimensions:

Area: $14,700 \mathrm{sf}$

Depth: $1.5 \mathrm{ft}$. minimum thickness

Provided storage volume: 0.198 acre feet

1 acre foot $=325,851.429$ gallons

$0.198 \times 325,851.429$ gallons $=64,518.58$ gallons

Required detention volume (100 year storm): 8637 cf

$8637 \mathrm{cf} / 43,560$ (cf in an acre foot) $=0.198$ acre feet $(64,518.58$ gallons) required 
Sources:

1. Emails and stormwater calculation spreadsheets provided by TERRA Engineering, Ltd.

2. Sheet C208 "Utility Plan" from the Bid Set dated 6/29/2009.

Note: The city of Chicago updated its stormwater calculation spreadsheet in 2014, after this project was completed. The project engineer stated that the using the new spreadsheet for this project would result in a $25 \%$ increase in storage requirements.

\section{Saves $1,126,712$ gallons of water per year with the park's low flow spray feature compared to the city's standard interactive feature. This saves over $\$ 4,200$ annually in water usage fees.}

\section{Method}

The water feature design provides significant cost savings through the use of misting heads and a series of activation bollards that allow visitors to trigger the water feature. Groups of 15 misting heads are mounted inside 5 stainless steel sculptural frames. When a user activates the water feature at one of the two bollards, it runs through a 3minute preprogramed misting sequence and shuts down. This sequence alternates the mist between the 5 different frames, with a maximum of 2 frames active at any one time. The use of activation bollards means that the water feature only runs when it has been activated by a visitor; this saves water since the feature is not running when there aren't any visitors.

Water feature water consumption:

15 Nozzles per frame $X 2$ frames $\max =30$ nozzles active at any one time 30 nozzles $X 0.0158$ gallons per minute $(\mathrm{gpm})=0.474 \mathrm{gpm}$ water consumption If the fountain is activate for 30 minutes per hour over a 12 hour period ( $8 \mathrm{AM}$ to 
8 PM), the fountain would use 170.64 gallons of water per day from the municipal water supply.

This can be compared to a traditional Chicago interactive splash feature, typically the "Three Arm Bandit" manufactured by Water Odyssey. The manufacturer of the Three Arm Bandit specifies the water consumption as $25-35 \mathrm{gpm}$. For these calculations, we utilized the median consumption rate of $30 \mathrm{gpm}$ :

1 unit $\times 30 \mathrm{gpm}=30 \mathrm{gpm}$ water consumption

If the fountain is activated for 30 minutes per hour over a 12 hour period ( $8 \mathrm{AM}$ to 8 PM), the fountain would use 10,800 gallons of water per day from the municipal water supply.

These consumption calculations show that the fountain at Mary Bartelme Park utilizes 98.42\% less water per day than the city's typical interactive water feature. Over a time period of Memorial Day - Labor Day (106 days in 2015), the savings would add up to over 1,126,712 gallons.

10,800 gallons (standard feature) - 170.64 gallons (Mary Bartelme feature) $=10,629.36$ gallons saved per day

$10,629.36 \times 106$ days $=1,126,712.16$ gallons saved per year

These savings becomes even more apparent when one compares the water consumption based on the current City of Chicago water service rate of $\$ 3.81$ per 1,000 gallons. Based on this cost, the Fountain at Mary Bartelme Park uses $\$ 0.65$ in water per day, compared with the standard Three Arm Bandit that would cost $\$ 41.15$ in water per day. That equates to a savings of $\$ 40.50$ per day. During the peak outdoor recreational period between Memorial Day and Labor Day (106 days in 2015), that equates to a savings of $\$ 4,292.77$ per summer in water usage fees.

Sources:

1. City of Chicago water rates: 
http://www.cityofchicago.org/city/en/depts/water/provdrs/cust serv/svcs/know my wate $\underline{r \text { sewerrates.html }}$

2. Water Odyssey Three Arm Bandit: http://waterodyssey.com/products/three-armbandit/

\section{Reduced local surface temperatures by over 25 degrees Fahrenheit through} the conversion of 48,460 sf of dark colored hardscape/rooftop areas into turf and perennial plantings.

The previous condition of the project site included 2 large buildings (25,006 sf) surrounded by large asphalt parking lots (64,276 sf). The buildings and the parking lots covered $89.3 \%$ of the 2.3 -acre site. The remaining 10,671 sf were turf and landscape areas. Construction of the park included the conversion of $48,460 \mathrm{sf}$ (1.11 acres) of asphalt and black-roofed building surface into lawn and perennial planting areas.
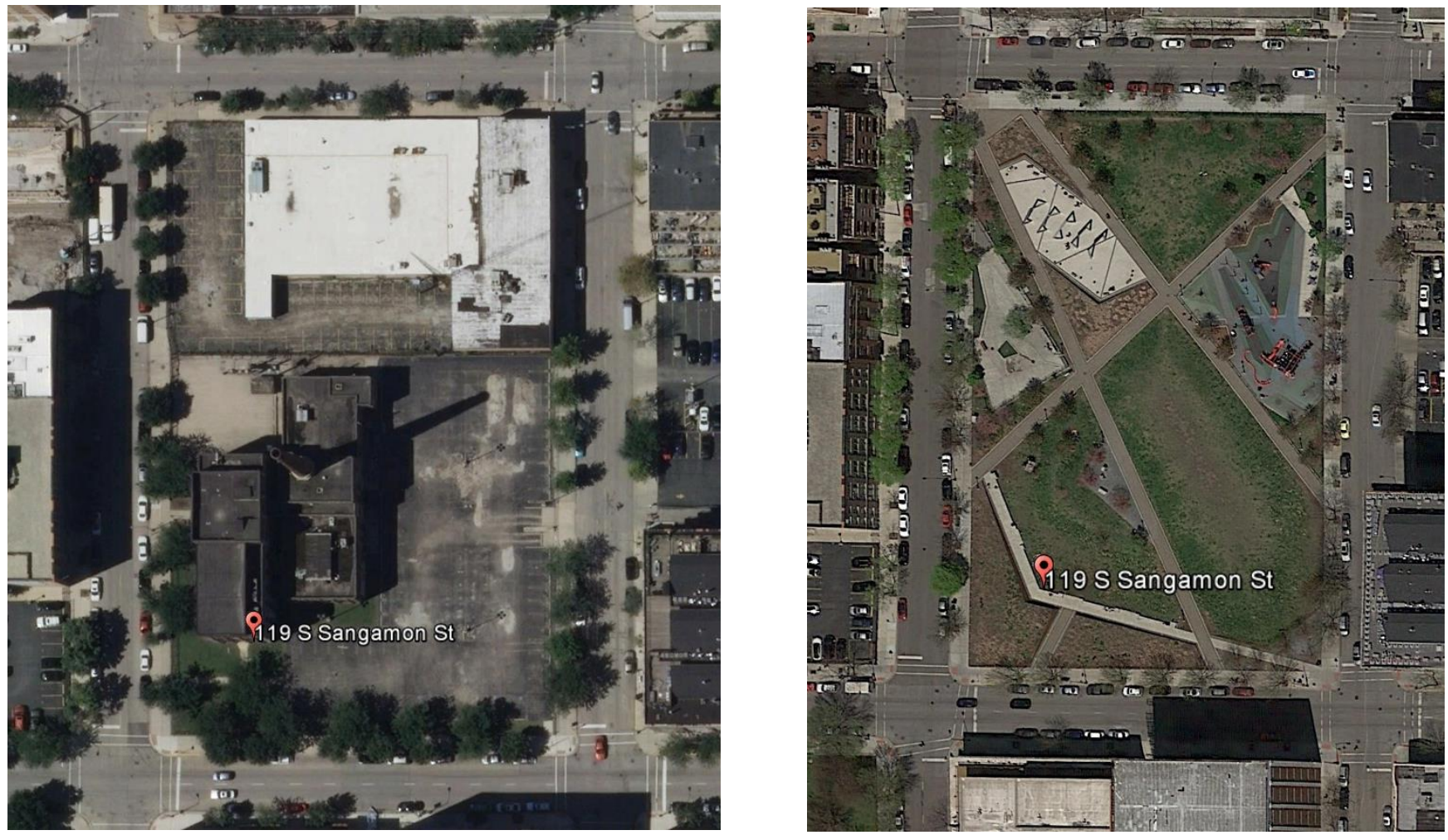

Aerial photo of the previous conditions on the site in 2008 (left) and the park in 2015 (right). Aerial photos from Google Earth. 


\section{Method}

In order to measure the temperature impact of this change, the CSI team compared surface temperatures of the new surfaces installed in the park and an existing parking lot located due east of the park. The existing parking lot provided a sampling point representative of the previous site conditions. Surface temperatures were measured in degrees Fahrenheit with a Ryobi IR002 hand held infrared thermometer on 06/28/2015 and 06/29/2015 during the peak afternoon temperatures. Measurements were taken at 2:30PM, 3:30PM, and 4:30PM and can be viewed in the chart below.

\begin{tabular}{|c|c|c|c|c|c|c|c|}
\hline & \multicolumn{3}{|c|}{$\begin{array}{l}\text { Field } \\
\text { Measurements } \\
\text { Units: Degrees } \\
\text { Fahrenheit }\end{array}$} & \multicolumn{4}{|c|}{$\begin{array}{l}\text { Difference compared to } \\
\text { asphalt } \\
\text { Units: Degrees } \\
\text { Fahrenheit }\end{array}$} \\
\hline 6/28/2015 & $\begin{array}{r}2: 30 \\
\text { PM }\end{array}$ & $\begin{array}{r}3: 30 \\
\text { PM }\end{array}$ & $\begin{array}{r}4: 30 \\
\text { PM }\end{array}$ & $\begin{array}{r}2: 30 \\
P M\end{array}$ & $\begin{array}{r}3: 30 \\
\text { PM }\end{array}$ & $\begin{array}{r}4: 30 \\
\text { PM }\end{array}$ & \\
\hline \multicolumn{8}{|c|}{ Weather conditions: Partly cloudy } \\
\hline Air temperature & 78.5 & 79.0 & 79.5 & & & & \\
\hline $\begin{array}{l}\text { Adjacent asphalt (previous } \\
\text { condition) }\end{array}$ & 97.5 & 98.7 & 99.1 & & & & $\begin{array}{l}\text { Daily } \\
\text { Avg. }\end{array}$ \\
\hline White pavers & 103.4 & 104.5 & 104.7 & 5.9 & 5.8 & 5.6 & 5.8 \\
\hline Medium pavers & 108.5 & 109.8 & 110.1 & 11.0 & 11.1 & 11.0 & 11.0 \\
\hline Dark pavers & 108.7 & 109.9 & 110.2 & 11.2 & 11.2 & 11.1 & 11.2 \\
\hline Plain concrete sidewalks & 94.4 & 95.6 & 97.1 & -3.1 & -3.1 & -2.0 & -2.7 \\
\hline Lawn areas & 68.1 & 68.7 & 75.8 & -29.4 & -30.0 & -23.3 & -27.6 \\
\hline $6 / 29 / 2015$ & $\begin{array}{r}2: 30 \\
\text { PM }\end{array}$ & $\begin{array}{r}3: 30 \\
\text { PM }\end{array}$ & $\begin{array}{r}4: 30 \\
\text { PM }\end{array}$ & $\begin{array}{r}2: 30 \\
\text { PM }\end{array}$ & $\begin{array}{r}3: 30 \\
\text { PM }\end{array}$ & $\begin{array}{r}4: 30 \\
\text { PM }\end{array}$ & \\
\hline \multicolumn{8}{|c|}{ Weather conditions: Partly cloudy } \\
\hline Air temperature & 71.5 & 73.0 & 74.5 & & & & \\
\hline $\begin{array}{l}\text { Adjacent asphalt (previous } \\
\text { condition) }\end{array}$ & 104.5 & 105.1 & 105.5 & & & & $\begin{array}{l}\text { Daily } \\
\text { Avg. }\end{array}$ \\
\hline
\end{tabular}




\begin{tabular}{|l|r|r|r|r|r|r|r|} 
White pavers & 102.6 & 103.4 & 103.7 & -1.9 & -1.7 & -1.8 & $\mathbf{- 1 . 8}$ \\
\hline Medium pavers & 111.4 & 112.5 & 112.9 & 6.9 & 7.4 & 7.4 & $\mathbf{7 . 2}$ \\
\hline Dark pavers & 110.5 & 110.9 & 112.1 & 6.0 & 5.8 & 6.6 & $\mathbf{6 . 1}$ \\
\hline Plain concrete sidewalks & 103.7 & 104.4 & 105.0 & -0.8 & -0.7 & -0.5 & $\mathbf{- 0 . 7}$ \\
\hline Lawn areas & 80.6 & 81.1 & 82.2 & -23.9 & -24.0 & -23.3 & $\mathbf{- 2 3 . 7}$ \\
\hline
\end{tabular}

Upon comparison of the temperatures of the new surfaces with the temperatures of the parking lot (representing the previous conditions), some surprising revelations appeared. On average, the surface temperatures of the lawn areas were substantially less than the temperature of the adjacent asphalt (by 25.3\%). The average temperature difference between the asphalt and the lawn was 25.65 degrees, with a maximum recorded difference of 30.0 degrees. This shows that green space has helped lower surface temperatures in this urban setting.

One result that stood out to the CSI team was that surface temperatures of colored concrete pavers, even those in lighter shades, averaged higher temperatures than those of the asphalt parking lot. Most assume that a lighter colored paving reflects more heat than darker pavements. In fact, the plain concrete measured at a lower temperature than the concrete pavers and the asphalt. The team identified several research teams that have found similar results and who are investigating further into the albedo (reflected and retained heat) of various materials.

Links to studies of effects of Albedo on temperatures:

https://ncesmart.asu.edu/docs/smart/unintended-consequences-1013.pdf

\section{http://fullcircle.asu.edu/faculty/paving-the-way-to-a-cooler-future/}

\section{http://www.asphaltfacts.com/news/industry-news/research-findings-concrete-}

\section{pavements-make-urban-heat-islands-worse-not-better/}


Limitations: The quantity of data points is the most apparent limitation, weekly sampling over a one-year time period would provide a more extensive data set that could also evaluate the potential effects of seasonal variations in air temperature.

\section{SOCIAL}

\section{Attracts over 2,000 people per year for 10 major programmed events.}

Mary Bartelme Park is utilized for numerous events throughout the year, some coordinated on the city level and others organized by the Park Advisory Committee. Yearly major organized activities include:

- "The Big Find" Easter Egg Hunt, 350-400 attendees, Sponsor: Soul City Church

- Clean \& Green Volunteer Events (a park beautification event), 2 per year, averaging 20-30 attendees, Sponsor: Park Advisory Council

- Movie Night, 2 per year, averaging 250-300 attendees, Sponsor: West Loop Community Organization

- DJ in the Park, 75-100 attendees, Sponsor: Chicago Park District

- Party for the Park Fundraising Event, 500-600 attendees, Sponsor: West Loop Community Organization

- 'Howl-o-ween' Pet Event, 50-100 attendees, Sponsor: West Loop Veterinary Care

- West Loop Families Halloween Parade, 200-250 attendees, Sponsor: West Loop Families

- Holiday Tree and Menorah Lighting Ceremony, 250-300 attendees, Sponsor: West Loop Community Organization

Weekly events during the summer months:

- Saturday mornings in the summer: Yoga in the Park

- Weekdays in the summer: Fit4Mom morning exercise classes 
In addition to these formal events, the park plays host for many informal events and activities. While observing the park and taking surveys, the CSI team witnessed several business meetings taking place in the park. Groups of 2-4 business professionals would "walk and talk" around the park or claim a section of seating to hold their meetings.

2015 Event calendar:

\begin{tabular}{|c|c|c|c|c|c|c|}
\hline \multicolumn{7}{|c|}{ Winter } \\
\hline \multicolumn{7}{|c|}{ January } \\
\hline $\mathrm{S}$ & $\mathrm{M}$ & $T$ & W & $T$ & $\mathrm{~F}$ & $\mathrm{~S}$ \\
\hline & & & & 1 & 2 & 3 \\
\hline 4 & 5 & 6 & 7 & 8 & 9 & 10 \\
\hline 11 & 12 & 13 & 14 & 15 & 16 & 17 \\
\hline 18 & 19 & 20 & 21 & 22 & 23 & 24 \\
\hline 25 & 26 & 27 & 28 & 29 & 30 & 31 \\
\hline & & & & & & \\
\hline
\end{tabular}
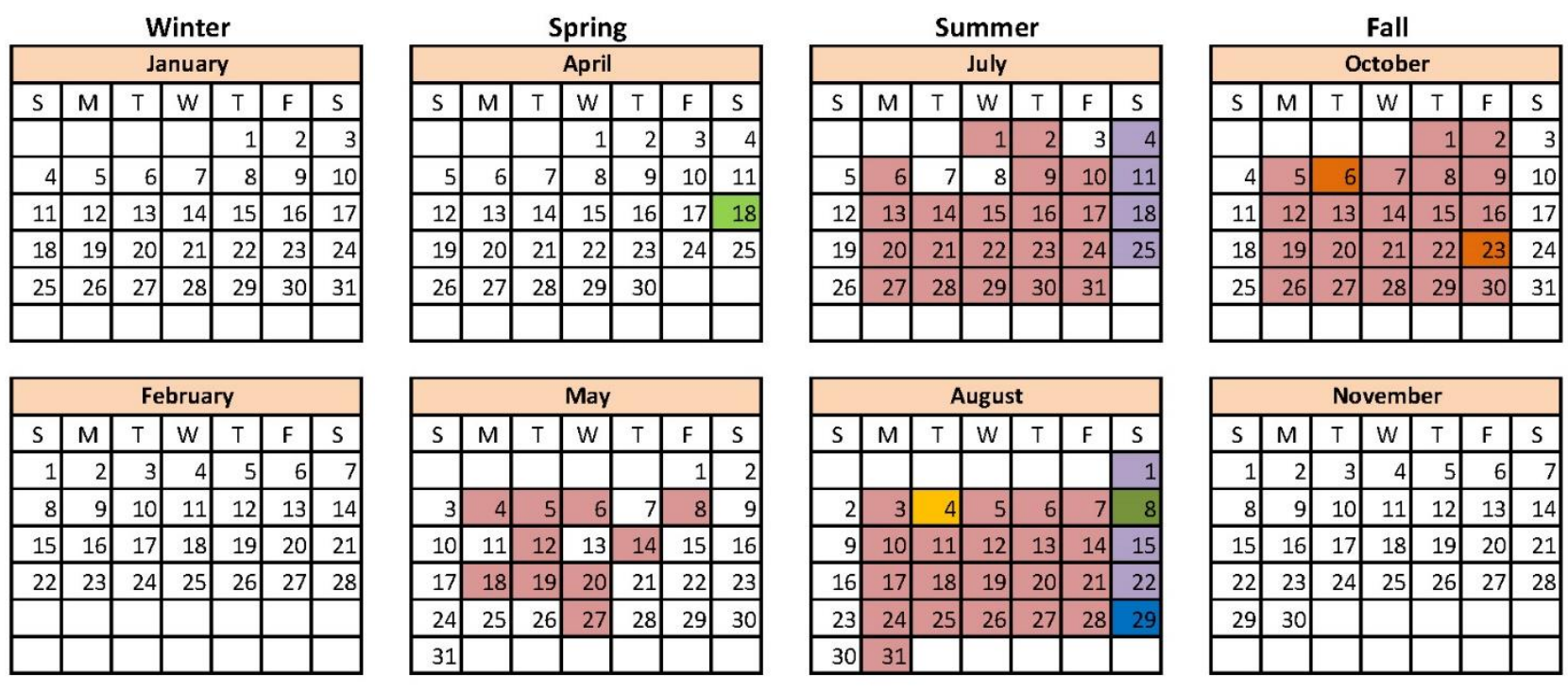

\begin{tabular}{|r|r|r|r|r|r|r|}
\hline \multicolumn{7}{|c|}{ March } \\
\hline S & M & $T$ & W & T & F & S \\
\hline 1 & 2 & 3 & 4 & 5 & 6 & 7 \\
\hline 8 & 9 & 10 & 11 & 12 & 13 & 14 \\
\hline 15 & 16 & 17 & 18 & 19 & 20 & 21 \\
\hline 22 & 23 & 24 & 25 & 26 & 27 & 28 \\
\hline 29 & 30 & 31 & & & & \\
\hline & & & & & & \\
\hline
\end{tabular}
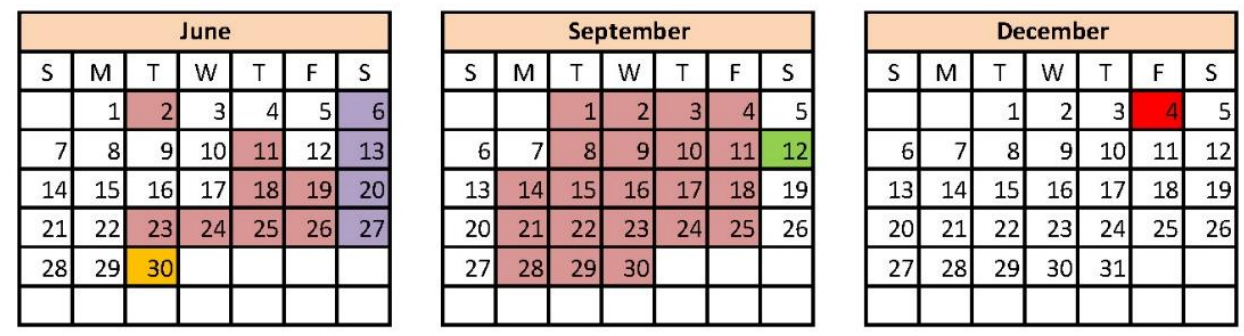

Event Key
\begin{tabular}{|l}
\hline \\
Fit4Mom morning exercise \\
Yoga in the park \\
Easter Egg Hunt \\
Movie night \\
Party for the Park
\end{tabular}

Clean \& Green clean-up event DJ in the Park Howl-o-ween' and Family Halloween Parade Holiday Tree and Menorah Lighting Ceremony

\section{Sources:}

1. Correspondence with the Mary Bartelme Park Advisory Council

2. Advisory Council website: http://www.westlooppark.com/\#!events/c16ck

3. Data provided by the Chicago Parks Department 


\section{Supports alternative modes of transportation, only $10 \%$ of weekday and $18 \%$ of weekend users arrived at the park via automobiles. $82 \%$ of weekday park users travel less than 10 minutes to get to the park.}

\section{Method}

In order to gain a better understanding of the impact of the Mary B Park on proximate neighbors, as well as the wider extent of that impact, we created a survey that was administered on site for two consecutive days: June 28-29, 2015. The objectives of the instrument (see Appendix A \& B) were 1) to learn how far visitors to the park would travel and what modes of transit they used;2) what attractions did they find most notable at the park; and 3) what impact (if any) their experiences at the park might have had on their connections and perception toward the neighborhood.

First, a survey instrument and protocols were developed for the purpose of securing a waiver from Internal Review Board. Once this was secured (6/17/15), the team was free to begin approaching residents. All data collected was anonymous; after checking an informed consent clause, numbered surveys were issued to visitors; this technique permitted the verification of consent, but also preserved the anonymity of data we collected.

\begin{tabular}{|l|c|c|c|c|c|c|}
\hline Day & Date & 8:30 AM & 10:30 AM & 12:30 PM & 2:30 PM & 4:30 PM \\
\hline Sunday & $6 / 28 / 2015$ & --- & --- & $X X$ & $X X$ & $X X$ \\
\hline Monday & $6 / 29 / 2015$ & $\mathrm{XX}$ & $\mathrm{XX}$ & $\mathrm{XX}$ & $\mathrm{XX}$ & $\mathrm{XX}$ \\
\hline
\end{tabular}

Note: $X X$ indicates times when the survey was administered on site

\section{Findings}

Through on-site interviews of visitors, we determined that half $(50 \%)$ of the park users who filled out a survey $(n=44)$ lived within the park's zip code (60607). However, 
the impact of the park extends well beyond the proximate streets. Mary Bartelme Park draws visitors from all over Chicago, attracting local visitors from 12 additional Chicago area zip codes. In addition to Chicago-area visitors, 4 interviewees lived outside the state of Illinois, including Ohio, Indiana, New York, and Texas.
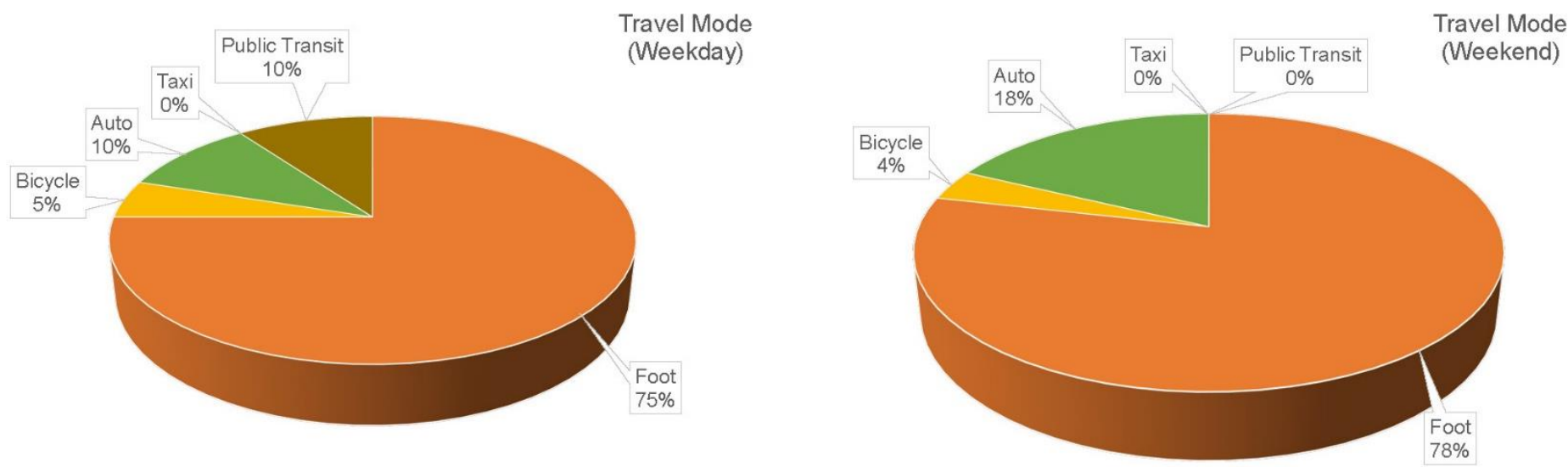

During the week, $82 \%$ of those people surveyed $(n=17)$ traveled less than 10 minutes to get to the park. That percentage dropped on the weekend, with only $68 \%$ of surveyed visitors travelling less than 10 minutes to get to the park. Only $10 \%$ of weekday users and $18 \%$ of weekend users arrive at the park via automobile. This is most likely influenced by the limited amount of on street parking near the park. $78 \%$ of the weekend visitors and $75 \%$ of the weekday visitors travelled to the park on foot. On the weekday, other modes of travel included bicycle (5\%) and public transit (10\%). On the weekend, other modes of travel included bicycle (4\%). 




Map of surrounding zip codes and the number of survey takers per zip code. 

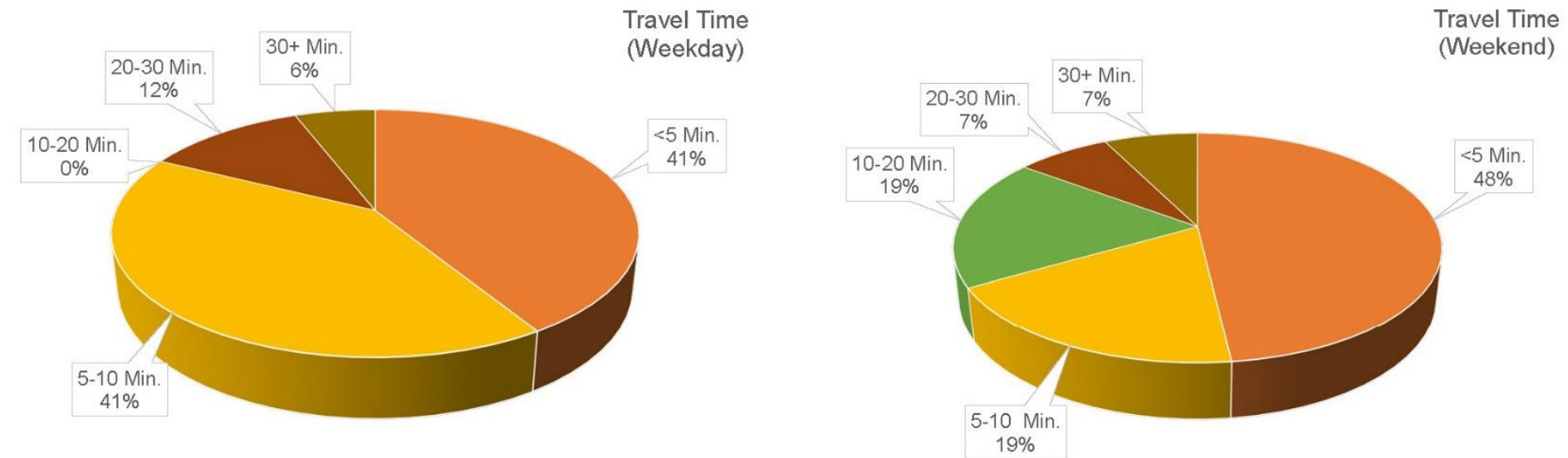

Based on the survey data, we were also able to determine that the playground and the dog park were the top two attractions for visitors, totaling over $58 \%$ of interviewees. Those two features split that $56 \%$ evenly at $28 \%$ each. Other park features that attracted visitors were the wild flowers (12\%), city views (12\%), water feature $(8 \%)$, and other $(12 \%)$, which included people walking through the park on their way to a different destination.


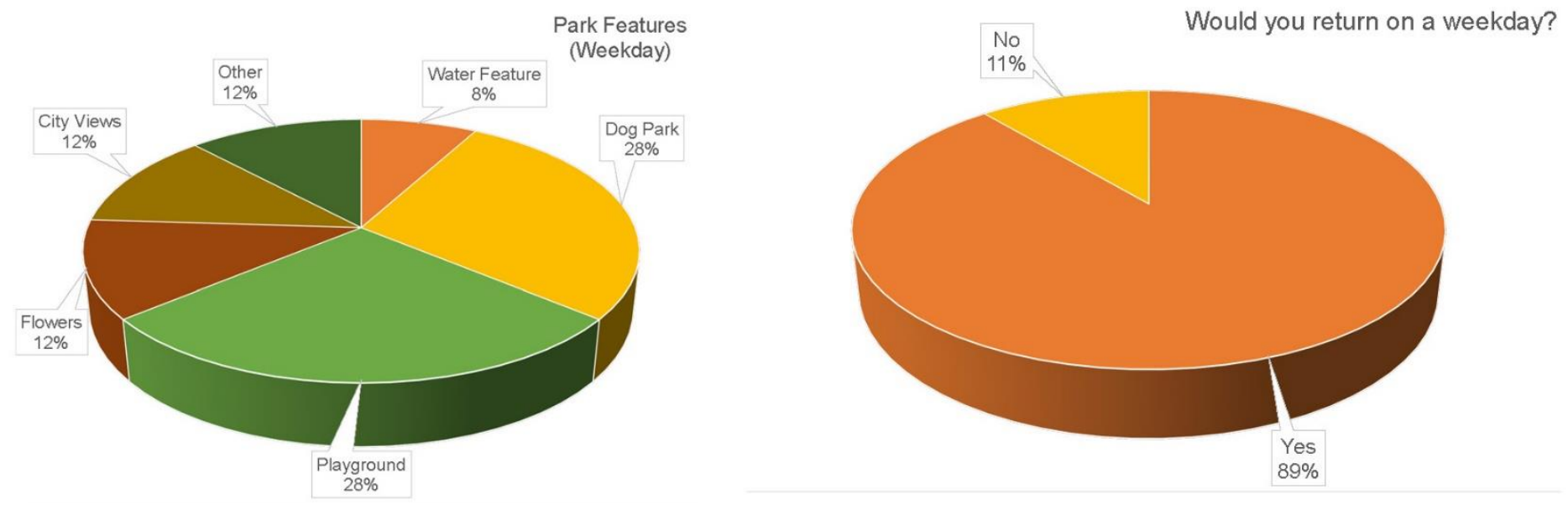

Source:

In-person survey, see appendix for copies of the survey form. The park features entrances at all 4 corners, so the surveyor rotated to a different entrance every 15 minutes for a total of 1 hour. In order to make the surveyor appear more official, a sign that stated "Park Impact Study" with the logos for the University of Illinois and the Landscape Architecture Foundation was attached to the fencing/railing adjacent to where he stood. A name tag was also created to make the surveyor appear more approachable.

Note: On Sunday afternoon, park visitors were far more willing to stop and fill out a survey than they were on Monday. On Monday, most park visitors-even those that were there with dogs and/or children-stated that they were in a hurry and were not willing to stop and fill out the survey.

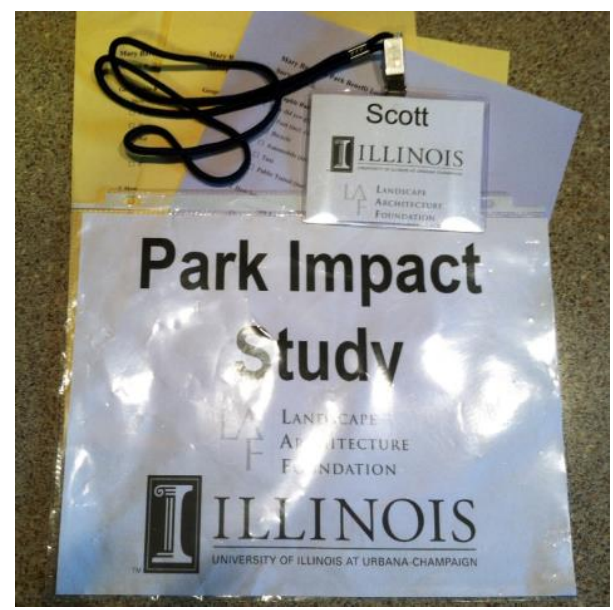




\section{ECONOMIC}

\section{Generates $\$ 5,660$ per year in event permit fees.}

All parks in the Chicago Park District may be rented for public and private events. While the specific amount of revenue from fees was not available from the park district, the CSI team was able to use the park district's 2015 special event permit application form to estimate the fees for the scheduled events at the park. Fees are based on number of attendees and the type of activities that will be occurring during the event.

\begin{tabular}{|l|l|lc|}
\hline \multicolumn{4}{|c|}{ Mary Bartelme Park Event Fees } \\
\hline Event & \# People & \multicolumn{2}{l|}{ Fee } \\
\hline Easter egg hunt & $350-400$ & $\$$ & 685.00 \\
\hline Movie night 1 & $250-300$ & $\$$ & 685.00 \\
\hline Movie night 2 & $250-300$ & $\$$ & 685.00 \\
\hline DJ in the park & $75-100$ & $\$$ & 145.00 \\
\hline Fundraiser & $500-600$ & $\$$ & $1,540.00$ \\
\hline Howl-o-ween & $50-100$ & $\$$ & 145.00 \\
\hline Halloween & $200-250$ & $\$$ & 685.00 \\
\hline Holiday tree & $250-300$ & $\$$ & 685.00 \\
\hline Exercise group & yearly fee & $\$$ & 405.00 \\
\hline & Total: & $\$$ & $\mathbf{5 , 6 6 0 . 0 0}$ \\
\hline
\end{tabular}

Source:

2015 Chicago Park District special event permit application.

2. Provides a setting for numerous small businesses to operate, including: fitness classes that generate over $\$ 7,500$ per year, food vendors, and professional photographers.

The park grounds provide an area for small businesses to capitalize on the large open spaces, unique city views, and interesting site elements. The park hosts a variety of 
professionally lead fitness training groups for moms (weekday mornings) and yoga classes (Saturday mornings) during the summer season. If a company is going to host events that participants pay to attend, they have to acquire a $\$ 405 /$ year permit from the parks department.

CLASSES: The weekday exercise groups for moms focus on stroller based exercises for mothers and they cost a minimum of $\$ 15$ per visit. Attendance numbers for these group events range from 1-10 participants. Based on an average attendance of 5 people, each class generates $\$ 75$. With 101 days listed on their calendar for 2015 , these classes generate an estimated $\$ 7,575$ per year. 2015 is the second year that the company has hosted these classes at the park, so it generated enough profits in 2014 to justify reacquiring the yearly permit to operate in the park.

FOOD VENDORS: In addition to these fitness classes, the park has also attracted a smoothie and hotdog vendor to the area. That vendor has received a permit from the parks department to locate the stand on the northwest corner of the park, adjacent to the water feature. A company representative stated that this location for the business (its fourth location) has created several part time jobs, pays permit fees to the parks department, and is a needed source for food and drink right at the outside edge of the park. Specific revenue numbers were not made available to the CSI team. In addition to this food vendor, the city of Chicago has created a food truck parking area with space for two trucks on W. Adams Street at the park. This addition of a food truck location increases the number of businesses that can benefit from the quantity of people that the park attracts. Since food trucks follow an irregular schedule, notifying patrons of their location via social media, the CSI team was unable to identify how many trucks visit the park, how often they are there, or how much revenue is generated at the park.

PHOTO OPPORTUNITES: Local professional photographers have also found the park to be a location where they can capitalize on the visual interest of the sculptural fountain and the skyline views by using the park as a setting for photo shoots. A resident of a condo that overlooks the park stated that photographers can been seen taking portraits in the park every weekend when the weather is nice. One person who filled out a survey on the weekend was there for a family photography session. 
Photography sessions typically cost between $\$ 200-375$, depending on the time frame, which can range between 30-90 minutes.

PETS: In addition to these businesses that depend on the park to provide a physical setting for their business, a pet store that is located across the street from the park also benefits from the foot traffic that is generated by the park. While the owner stated that the park itself was not a determining factor in the selection of their corner store front, she did state that over $50 \%$ of her clientele utilize the park and the dog park within the park.

Sources:

In person, phone, and email interviews with business owners and review of business websites for events at the park.

Food truck: http://chicago.suntimes.com/politics/7/71/171226/chicago-to-add-ninemore-dedicated-stands-for-mobile-food-trucks

https://fit4mom-chicagoloop.frontdeskhq.com/locations/bartelme-mary-park-westloop\#/month?dt=2015-07-13\&lt=staff

\section{Provides a location for free yoga classes for the general public, worth over $\$ 8,910$ per year.}

Attendance at the Saturday morning yoga classes, which are held June through August, averages 35 people per week and had 75 participants at their special $4^{\text {th }}$ of July morning session. While a typical yoga class with this local yoga studio costs $\$ 18$ per session to participate, these park sessions are provided for free. This is a total cost savings of over $\$ 630$ per week ( $\$ 8,910$ per year) for users. The yoga studio representative stated that these free outdoor sessions are a great recruitment tool for their studio, which is located 1 block west of the park. While they would not offer any detailed numbers on revenue generated by the Saturday park sessions, the representative stated that it has "been great to spread the word about our studio." 


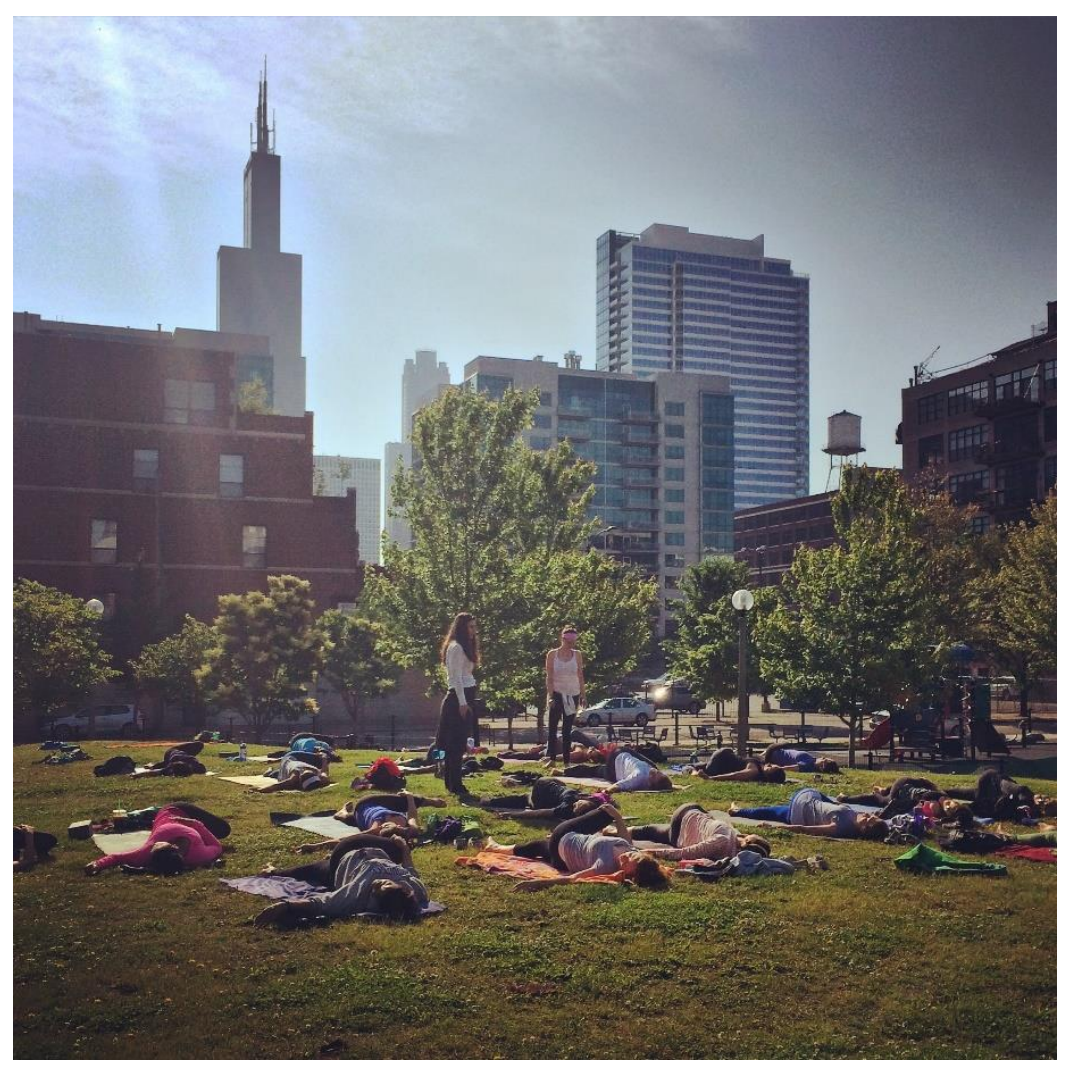

Yoga in the park event. Photo by Robin French, Bare Feet Power Yoga.

Email interviews with business owners and review of the company website:

\section{http://barefeetpoweryoga.com/events/4th-of-july-class-at-the-park/}

\section{Would motivate $82 \%$ of park users interviewed to consider relocating to the area.}

To further evaluate what impact (if any) their experiences at the park might have had on visitors' perception toward the neighborhood, the CSI survey included this question: "If you were thinking about relocating your home or business, would this park motivate you to move into the surrounding area?" $82 \%$ of the weekday park visitors who participated in our survey answered 'yes,' showing that the park is seen as positive motivator for relocating homes and businesses to the surrounding neighborhood. When 
asked "to what extent it would motivate," $71 \%$ of those who answered yes rated the park's influence as "definitely motivating" or "motivating."

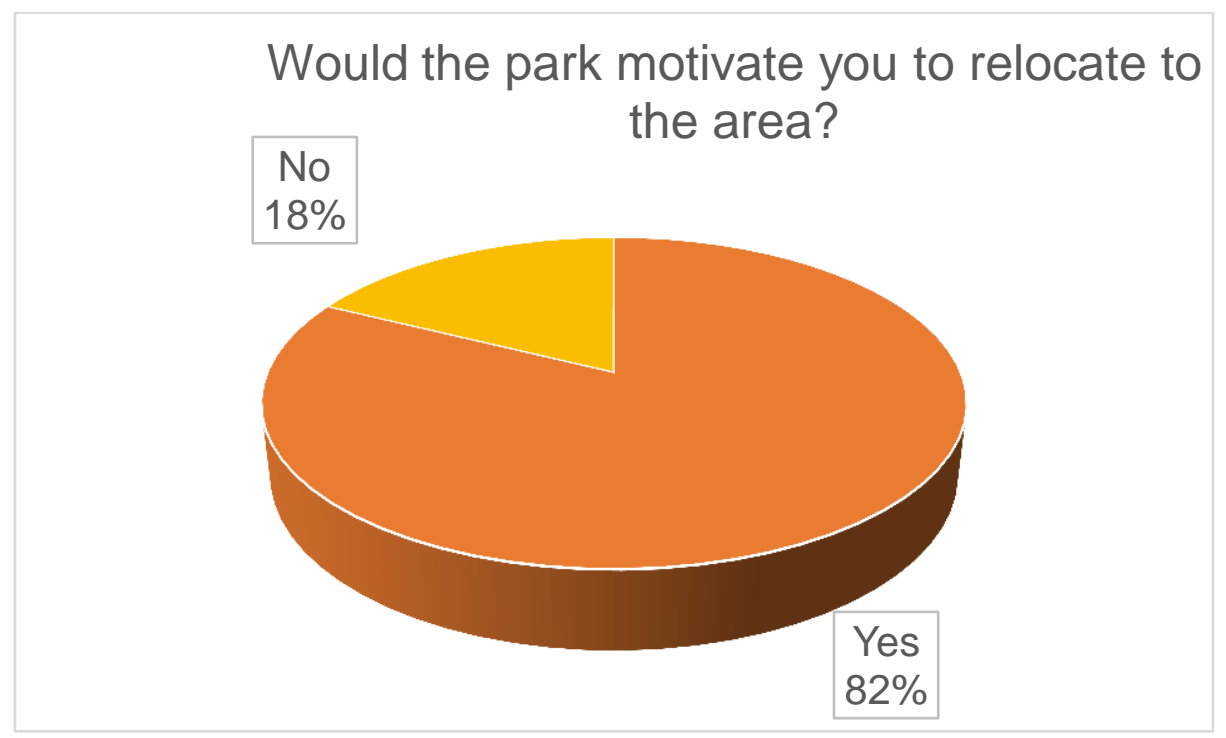

Source:

In person survey, see appendix for copies of the survey form.

5. Helps to increase property values within a 2 block radius by $49.88 \%$ over the average property value within the park's zip code.

The park is located in what many describe as a "trendy" and "prime" location to live. What were once dilapidated warehouse and industrial buildings now contain offices, businesses and residential condominiums and lofts. The redevelopment of the west loop area began in 1990 when Oprah Winfrey located her Harpo Studios on Washington Street, just 2 blocks north and 2 blocks west of Mary Bartelme Park.

The CSI team collected and reviewed available sales data on sold properties that were located within a two-block radius of Mary Bartelme Park. Pro block area sold for an average price of $\$ 376,954.55$ in 2014 and 2015 . When sale prices of those properties are compared to the average home price within the park's zip code (60607) 
of $\$ 251,500.00$, the properties within two blocks of the park had average price increases of $49.88 \%$ over the zip code average. When compared to the average home price for the Chicago metro area $(\$ 188,000.00)$ that percent increase climbed to $100.51 \%$.

The CSI team also located 2 properties with sales pending (July 2015) and those properties showed an average price increase of $87.87 \%$ over the zip code average and $151.33 \%$ increase over the Chicago metro average. When the team compared the prices of properties that are currently listed for sale, the differences increased even further. The 7 properties currently listed for sale averaged an increase of $105.84 \%$ over the zip code average and a $175.36 \%$ increase over the Chicago metro average.

Based on the price increases from those properties sold in 2014/2015 to the properties that are sale pending or currently listed for sale, the property values around the park are continuing to increase. An area real estate agent verified this and also stated that "buyers will pay more to be close to the park," and that "the park is mentioned in almost all listings for properties close to the park."

\begin{tabular}{|c|c|c|c|c|c|c|}
\hline \multirow{2}{*}{\multicolumn{3}{|c|}{$\begin{array}{l}\text { Comparison of property values within a } 2 \text { block radius } \\
\text { of the park to the average price within the park's zip } \\
\text { code (60607) and the average price in the Chicago } \\
\text { metro area }\end{array}$}} & \multicolumn{2}{|c|}{$\begin{array}{l}\text { Average home price in zip } \\
\text { code (60607) }\end{array}$} & \multicolumn{2}{|c|}{$\begin{array}{l}\text { Average home price in the } \\
\text { City of Chicago }\end{array}$} \\
\hline & & & Average & $\$$ & & $\$$ \\
\hline & & & Difference & & Difference & \\
\hline Currently listed for sale & $\begin{array}{l}\text { Sale } \\
\text { year }\end{array}$ & Price & $\begin{array}{c}\text { from average } \\
\text { price }\end{array}$ & $\begin{array}{l}\text { Percent } \\
\text { increase }\end{array}$ & $\begin{array}{c}\text { from average } \\
\text { price }\end{array}$ & $\begin{array}{l}\text { Percent } \\
\text { increase }\end{array}$ \\
\hline 100 S Sangamon St 4s & --- & $\$ 899,000.00$ & $\$ 647,500.00$ & $257.46 \%$ & $\$ 711,000.00$ & $378.19 \%$ \\
\hline 850 W Adams Apt 4b & --- & $\$ 700,000.00$ & $\$ 448,500.00$ & $178.33 \%$ & $\$ 512,000.00$ & $272.34 \%$ \\
\hline 842 W Adams St FL2 & --- & $\$ 310,000.00$ & $\$ 58,500.00$ & $23.26 \%$ & $\$ 122,000.00$ & $64.89 \%$ \\
\hline 950 W Monroe St Apt 916 & --- & $\$ 685,000.00$ & $\$ 433,500.00$ & $172.37 \%$ & $\$ 497,000.00$ & $264.36 \%$ \\
\hline $\begin{array}{l}949 \text { W Madison St Apt } \\
404\end{array}$ & --- & $\$ 245,000.00$ & $\$(6,500.00)$ & $-2.58 \%$ & $\$ 57,000.00$ & $30.32 \%$ \\
\hline
\end{tabular}




\begin{tabular}{|c|c|c|c|c|c|c|}
\hline 111 S Morgan St Apt 307 & --- & $\$ 384,900.00$ & $\$ 133,400.00$ & $53.04 \%$ & $\$ 196,900.00$ & $104.73 \%$ \\
\hline \multicolumn{7}{|l|}{949 W Madison St Apt } \\
\hline \multirow[t]{2}{*}{401} & --- & $\$ 399,900.00$ & $\$ 148,400.00$ & $59.01 \%$ & $\$ 211,900.00$ & $112.71 \%$ \\
\hline & Average: & $\$ 517,685.71$ & Average: & $105.84 \%$ & Average: & $175.36 \%$ \\
\hline \multicolumn{7}{|l|}{ Sale pending } \\
\hline 111 S Morgan St Apt 523 & 2015 & $\$ 390,000.00$ & $\$ 138,500.00$ & $55.07 \%$ & $\$ 202,000.00$ & $107.45 \%$ \\
\hline \multirow[t]{2}{*}{1025 W Monroe St } & 2015 & $\$ 555,000.00$ & $\$ 303,500.00$ & $120.68 \%$ & $\$ 367,000.00$ & $195.21 \%$ \\
\hline & Average: & $\$ 472,500.00$ & Average: & $87.87 \%$ & Average: & $151.33 \%$ \\
\hline \multicolumn{7}{|l|}{ Sold } \\
\hline 950 W Monroe St 803 & 2015 & $\$ 400,000.00$ & $\$ 148,500.00$ & $59.05 \%$ & $\$ 212,000.00$ & $112.77 \%$ \\
\hline \multicolumn{7}{|l|}{939 W Madison St Apt } \\
\hline 405 & 2015 & $\$ 368,000.00$ & $\$ 116,500.00$ & $46.32 \%$ & $\$ 180,000.00$ & $95.74 \%$ \\
\hline \multicolumn{7}{|l|}{901 W Madison St Unit } \\
\hline 712 & 2014 & $\$ 368,500.00$ & $\$ 117,000.00$ & $46.52 \%$ & $\$ 180,500.00$ & $96.01 \%$ \\
\hline \multicolumn{7}{|l|}{1040 W Adams St Unit } \\
\hline 321 & 2014 & $\$ 372,000.00$ & $\$ 120,500.00$ & $47.91 \%$ & $\$ 184,000.00$ & $97.87 \%$ \\
\hline \multicolumn{7}{|l|}{950 W Monroe St Unit } \\
\hline 701 & 2014 & $\$ 375,000.00$ & $\$ 123,500.00$ & $49.11 \%$ & $\$ 187,000.00$ & $99.47 \%$ \\
\hline \multicolumn{7}{|l|}{1040 W Adams St Unit } \\
\hline 248 & 2014 & $\$ 380,000.00$ & $\$ 128,500.00$ & $51.09 \%$ & $\$ 192,000.00$ & $102.13 \%$ \\
\hline \multicolumn{7}{|l|}{939 W Madison St Apt } \\
\hline 410 & 2015 & $\$ 380,000.00$ & $\$ 128,500.00$ & $51.09 \%$ & $\$ 192,000.00$ & $102.13 \%$ \\
\hline \multicolumn{7}{|l|}{1040 W Adams St Unit } \\
\hline 327 & 2014 & $\$ 382,000.00$ & $\$ 130,500.00$ & $51.89 \%$ & $\$ 194,000.00$ & $103.19 \%$ \\
\hline \multicolumn{7}{|l|}{949 W Madison St Apt } \\
\hline 201 & 2015 & $\$ 390,500.00$ & $\$ 139,000.00$ & $55.27 \%$ & $\$ 202,500.00$ & $107.71 \%$ \\
\hline \multicolumn{7}{|l|}{933 W Van Buren St Apt } \\
\hline 501 & 2015 & $\$ 435,000.00$ & $\$ 183,500.00$ & $72.96 \%$ & $\$ 247,000.00$ & $131.38 \%$ \\
\hline 843 W Adams St Apt 506 & 2015 & $\$ 295,500.00$ & $\$ 44,000.00$ & $17.50 \%$ & $\$ 107,500.00$ & $57.18 \%$ \\
\hline
\end{tabular}

Mary Bartelme Park LPS Methodology Page $\mathbf{2 3}$ of $\mathbf{3 2}$ 
The average house size in the 60607 zipcode is 1,350 square feet, which is 50 square feet less than the average of the properties that were used in this study. $69.2 \%$ of the residential properties in the zip code have 1 or 2 bedrooms, see the chart below for a comparison of the zip code average and the properties used in this study:

\begin{tabular}{|c|c|c|c|c|c|}
\hline \multicolumn{3}{|c|}{$\begin{array}{c}\text { Number of Bedrooms in } \\
\text { Residences in } 60607 \text { zip code }\end{array}$} & \multicolumn{3}{|c|}{$\begin{array}{l}\text { Number of Bedrooms in } \\
\text { Residences used in study }\end{array}$} \\
\hline Bedrooms & $\begin{array}{l}\text { \# of } \\
\text { units }\end{array}$ & Percentage & Bedrooms & $\begin{array}{l}\text { \# of } \\
\text { units }\end{array}$ & Percentage \\
\hline 0 & 613 & $7.5 \%$ & 0 & 0 & $0.0 \%$ \\
\hline 1 & 2872 & $35.3 \%$ & 1 & 1 & $5.0 \%$ \\
\hline 2 & 2755 & $33.9 \%$ & 2 & 16 & $80.0 \%$ \\
\hline 3 & 1424 & $17.5 \%$ & 3 & 3 & $15.0 \%$ \\
\hline 4 & 359 & $4.4 \%$ & 4 & 0 & $0.0 \%$ \\
\hline $5+$ & 111 & $1.4 \%$ & $5+$ & 0 & $0.0 \%$ \\
\hline
\end{tabular}

\begin{tabular}{|l|c|c|c|c|}
\hline \multicolumn{5}{|c|}{ Property Information for properties used in study } \\
\hline Currently listed for sale & $\begin{array}{l}\text { sale } \\
\text { year }\end{array}$ & Bedrooms & Baths & $\begin{array}{c}\text { Square } \\
\text { Ft. }\end{array}$ \\
\hline 100 S Sangamon St Apt 4s & --- & 3 & 2 & 1946 \\
\hline 850 W Adams Apt 4b & --- & 2 & 2 & 2200 \\
\hline 842 W Adams St Apt FL2 & --- & 2 & 1.5 & \\
\hline 950 W Monroe St Apt 916 & --- & 3 & 2 & 1600 \\
\hline 949 W Madison St Apt 404 & --- & 1 & 1 & \\
\hline 111 S Morgan St Apt 307 & --- & 2 & 2 & 1121 \\
\hline 949 W Madison St Apt 401 & --- & 2 & 2 & 1200 \\
\hline
\end{tabular}




\begin{tabular}{|c|c|c|c|c|}
\hline \multicolumn{5}{|l|}{ Sale pending } \\
\hline 111 S Morgan St Apt 523 & 2015 & 2 & 2 & 1121 \\
\hline 1025 W Monroe St Apt 3E & 2015 & 2 & 2 & 1600 \\
\hline \multicolumn{5}{|l|}{ Sold } \\
\hline 950 W Monroe St Apt 803 & 2015 & 2 & 2 & \\
\hline 939 W Madison St Apt 405 & 2015 & 2 & 2 & 1300 \\
\hline 901 W Madison St Unit 712 & 2014 & 2 & 2 & \\
\hline 1040 W Adams St Unit 321 & 2014 & 2 & 2 & 1200 \\
\hline 950 W Monroe St Unit 701 & 2014 & 2 & 2 & 1572 \\
\hline 1040 W Adams St Unit 248 & 2014 & 2 & 2 & 1250 \\
\hline 939 W Madison St Apt 410 & 2015 & 2 & 2 & 1300 \\
\hline 1040 W Adams St Unit 327 & 2014 & 2 & 2 & 1265 \\
\hline 949 W Madison St Apt 201 & 2015 & 2 & 2 & 1300 \\
\hline 933 W Van Buren St Apt 501 & 2015 & 3 & 2 & 1464 \\
\hline \multirow[t]{2}{*}{843 W Adams St Apt 506} & 2015 & 1 & 1 & 970 \\
\hline & Average: & 2.1 & 1.9 & 1400.6 \\
\hline $\begin{array}{l}\text { Zillow was the source for all } p \\
\text { data }\end{array}$ & & & & \\
\hline
\end{tabular}

In an attempt to offset the 50 square foot difference between the zip code average and the survey property average, the prices were also compared on a per square foot basis. The average price per square foot for all of the survey properties showed an increase of $74.85 \%$ over the average price per square foot for the zip code, with a minimum increase of $51.95 \%$.

Comparison of property values within a 2 block radius of the park to the average price within the park's zip code (60607) and the average price in the Chicago metro area
Average home price in zip code (60607)

Average sf:

1350 


\begin{tabular}{|c|c|c|c|c|c|c|}
\hline & & & & & Average price: & $\begin{array}{l}\$ \\
251,500.00\end{array}$ \\
\hline & & & & & Average sf price: & $\begin{array}{l}\$ \\
186.30\end{array}$ \\
\hline Currently listed for sale & $\begin{array}{l}\text { Sale } \\
\text { year }\end{array}$ & Price & Square ft. & $\begin{array}{l}\text { Cost per } \\
\text { sf }\end{array}$ & $\begin{array}{l}\text { Difference from } \\
\text { average sf price }\end{array}$ & $\begin{array}{l}\text { Percent } \\
\text { increase }\end{array}$ \\
\hline 100 S Sangamon St Apt 4s & --- & $\$ 899,000.00$ & 1946 & $\$ 461.97$ & 275.68 & $147.98 \%$ \\
\hline 850 W Adams Apt 4b & --- & $\$ 700,000.00$ & 2200 & $\$ 318.18$ & 131.89 & $70.79 \%$ \\
\hline 842 W Adams St Apt FL2 & $\begin{array}{c}-- \\
\end{array}$ & $\$ 310,000.00$ & --- & --- & --- & --- \\
\hline 950 W Monroe St Apt 916 & --- & $\$ 685,000.00$ & 1600 & $\$ 428.13$ & 241.83 & $129.81 \%$ \\
\hline 949 W Madison St Apt 404 & --- & $\$ 245,000.00$ & --- & --- & --- & --- \\
\hline 111 S Morgan St Apt 307 & $\begin{array}{l}-- \\
\end{array}$ & $\$ 384,900.00$ & 1121 & $\$ 343.35$ & 157.06 & $84.31 \%$ \\
\hline 949 W Madison St Apt 401 & --- & $\$ 399,900.00$ & 1200 & $\$ 333.25$ & 146.95 & $78.88 \%$ \\
\hline & Average: & $\$ 517,685.71$ & & & Average: & $102.35 \%$ \\
\hline
\end{tabular}

\begin{tabular}{|c|c|c|c|c|c|c|c|}
\hline \multicolumn{8}{|l|}{ Sale pending } \\
\hline 111 S Morgan St Apt 523 & 2015 & $\$ 390,000.00$ & 1121 & $\$ 347.90$ & $\$$ & 161.61 & $86.75 \%$ \\
\hline \multirow[t]{2}{*}{1025 W Monroe St Apt 3E } & 2015 & $\$ 555,000.00$ & 1600 & $\$ 346.88$ & $\$$ & 160.58 & $86.20 \%$ \\
\hline & Average: & $\$ 472,500.00$ & & & & Average: & $86.47 \%$ \\
\hline
\end{tabular}

\begin{tabular}{|c|c|c|c|c|c|c|c|}
\hline \multicolumn{8}{|l|}{ Sold } \\
\hline 950 W Monroe St Apt 803 & 2015 & $\$ 400,000.00$ & --- & --- & & - & --- \\
\hline 939 W Madison St Apt 405 & 2015 & $\$ 368,000.00$ & 1300 & $\$ 283.08$ & $\$$ & 96.78 & $51.95 \%$ \\
\hline 901 W Madison St Unit 712 & 2014 & $\$ 368,500.00$ & --- & --- & & - & --- \\
\hline 1040 W Adams St Unit 321 & 2014 & $\$ 372,000.00$ & 1200 & $\$ 310.00$ & $\$$ & 123.70 & $66.40 \%$ \\
\hline 950 W Monroe St Unit 701 & 2014 & $\$ 375,000.00$ & 1572 & $\$ 238.55$ & $\$$ & 52.25 & $28.05 \%$ \\
\hline 1040 W Adams St Unit 248 & 2014 & $\$ 380,000.00$ & 1250 & $\$ 304.00$ & $\$$ & 117.70 & $63.18 \%$ \\
\hline 939 W Madison St Apt 410 & 2015 & $\$ 380,000.00$ & 1300 & $\$ 292.31$ & $\$$ & 106.01 & $56.90 \%$ \\
\hline 1040 W Adams St Unit 327 & 2014 & $\$ 382,000.00$ & 1265 & $\$ 301.98$ & $\$$ & 115.68 & $62.09 \%$ \\
\hline 949 W Madison St Apt 201 & 2015 & $\$ 390,500.00$ & 1300 & $\$ 300.38$ & $\$$ & 114.09 & $61.24 \%$ \\
\hline
\end{tabular}




\begin{tabular}{|l|r|r|r|r|r|r|r|}
933 W Van Buren St Apt 501 & 2015 & $\$ 435,000.00$ & 1464 & $\$ 297.13$ & $\$$ & 110.83 & $59.49 \%$ \\
\hline 843 W Adams St Apt 506 & 2015 & $\$ 295,500.00$ & 970 & $\$ 304.64$ & $\$$ & 118.34 & $63.52 \%$ \\
\hline & Average: & $\$ 376,954.55$ & & & Average: & $\mathbf{5 6 . 9 8 \%}$ \\
\hline $\begin{array}{l}\text { Zillow was the source for all } \\
\text { property data }\end{array}$ & \multicolumn{3}{|l}{} & & & \\
\hline
\end{tabular}

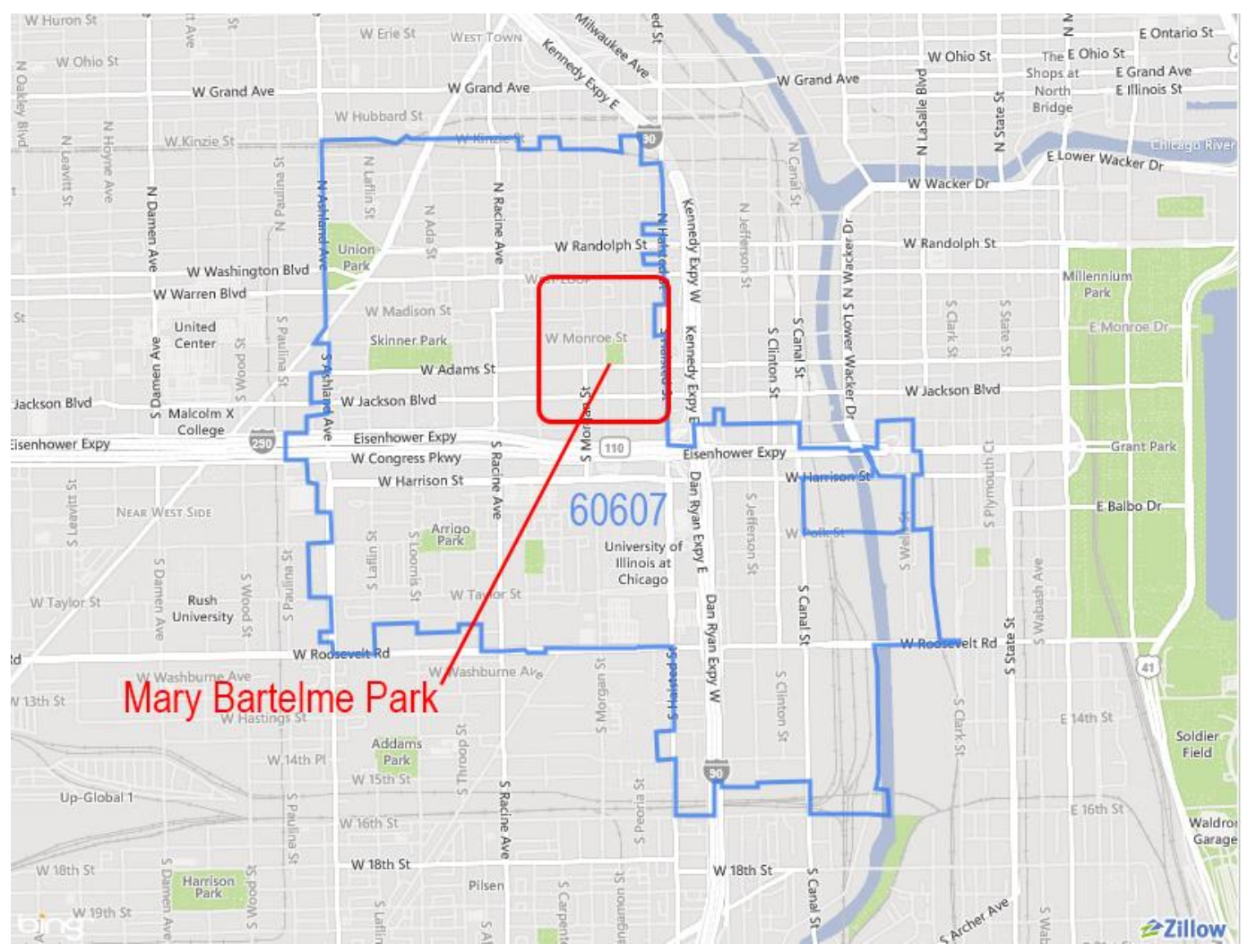

The location of Mary Bartelme Park in relation to the boundary for the 60607 zip code. Map from Google Maps.

Source:

All real estate data was collected from Zillow.com

Zip code demographic information retrieved from: http://www.movoto.com/chicagoil/ 60607/demographics/

Email correspondence with local real estate agent Armando Chacon, Principal of The Armando Chacon Group 
http://www.wbez.org/news/uber-gentrification-force-chicagos-west-loop-111257

\section{Cost Comparison}

Installation cost estimates for an irrigation system for the turf areas were calculated with a low and high estimate per square foot, $\$ 0.70$ and $\$ 1.00$ respectively. At these estimated costs, installation of an irrigation system for the turf areas $(52,370 \mathrm{sf})$ were estimated at between $\$ 36,659.00$ and $\$ 52,370.00$. This results in a median estimated construction cost of $\$ 44,514.50$.

In addition to the initial installation costs, the irrigation system would have incurred yearly costs including spring start up $(\$ 500.00)$, fall shut down $(\$ 500.00)$, back flow preventer testing (\$100.00), and other miscellaneous repairs due to damage from lawn mowers and park users $(\$ 1,000.00)$. Those yearly costs total up to $\$ 2,100.00$ in yearly expenditures, before taking into account water usage.

Water usage was estimated based on the system being operational from May 1 through October 31, a span of 30 weeks. If the system provides the required 1.5" of water every other week, it would apply 1.5 " of water 15 different times per season. Each application would require approximately 48,690 gallons of water to provide the required amount of water. At the city of Chicago's current water rate of $\$ 3.81$ per 1000 gallons, each application would cost $\$ 185.51$ in water consumption fees. 15 applications would result in a water bill of $\$ 2,782.70$ per year.

In total the decision to exclude an irrigation system from the project saved an estimated $\$ 44,514.50$ in construction costs and an addition $\$ 4,882.70$ per year in maintenance and water fees.

\section{Appendix}

\section{Mary Bartelme Survey Questions}

Mary Bartelme Park Benefit Impact Study: Regular Park Users 


\section{Survey \#}

\section{Geographic Radius of Users/Visitors}

1. How did you get to the park? (check one or more)

Foot (incl. skateboard)

Bicycle

Automobile (incl. motorbike)

$\square$ Taxi

$\square$ Public Transit (incl. local bus or train)

2. How long was your trip to the park today?

Less than 5 mins.

5-10 mins.

10-20 mins.

20-30 mins.

$30+$ mins.

What is your zip code? (see attached map)

\section{Frequency/Appeal}

3. Prior to this visit, how often do you visit Mary Bartelme Park?

Daily

Weekly

Seasonally

Special events

This is my first visit

4. What feature(s) do you come to the park for?

Water feature

Dog park

Playground

Wild flower plantings

City views

Other

5. If you were thinking about relocating your home or business, would this park have motivated you to move into the surrounding area?

$\square$ Yes

$\square$ No

To what extent?

Definitely would motivate Definitely would not motivate 
6. One Last Question: Why do you come to Mary Bartelme Park?

We ask you to sum up your feeling about this Park by completing the following sentence: "The biggest benefit of Mary Bartelme Park to (melfamily \neighborhoodlcommunitylcity) is:

Thank you very much for participating in the Mary Bartelme Park Benefit Impact Study!

\section{Mary Bartelme Park Benefit Impact Study: Weekend \& Event Park Users}

\section{Survey \#}

\section{Geographic Radius of Users/Visitors}

1. How did you get to the park? (check one or more)

Foot (incl. skateboard)

Bicycle

Automobile (incl. motorbike)

$\square$ Taxi

$\square$ Public Transit (incl. local bus or train)

2. How long was your trip to the park today?

Less than 5 mins.

5-10 mins.

10-20 mins.

20-30 mins.

$30+$ mins.

What is your zip code? (see attached map)

\section{Impact of Weekend/Events on Visitor Frequency}

3. Prior to this visit, how often do you visit Mary Bartelme Park?

Daily

Weekly

Seasonally

Special events 
This is my first visit

4. (OPTION \#1) Has attending the Park this weekend influenced the likelihood that you might revisit this park during a regular weekday $(\mathbf{M} / \mathrm{T} / \mathrm{W} / \mathrm{Th} / \mathbf{F})$ ?

Yes

$\square$ No

To what extent?

Strongly wish to visit again

Definitely will not revisit

1

2

3

4

5

Neutral

4. (OPTION \#2) Has attending this park event influenced the likelihood of you revisiting this park during a regular weekday $(\mathbf{M} / \mathrm{T} / \mathrm{W} / \mathrm{Th} / \mathbf{F})$ ?

Yes

No

To what extent?

Strongly wish to visit again

Definitely will not revisit

1

2

3

4

5

Neutral

5. One Last Question: Why do you come to Mary Bartelme Park?

We ask you to sum up your feeling about this Park by completing the following sentence: "The biggest benefit of Mary Bartelme Park to

(melfamily\neighborhoodlcommunitylcity) is:

Thank you very much for participating in the Mary Bartelme Park Benefit Impact Study!

\section{Additional Information}

A couple of the construction details that were developed for the rubber play surface at Mary Bartelme Park are now being used as standard details at other Chicago area parks. For reference, those details can be found below: 

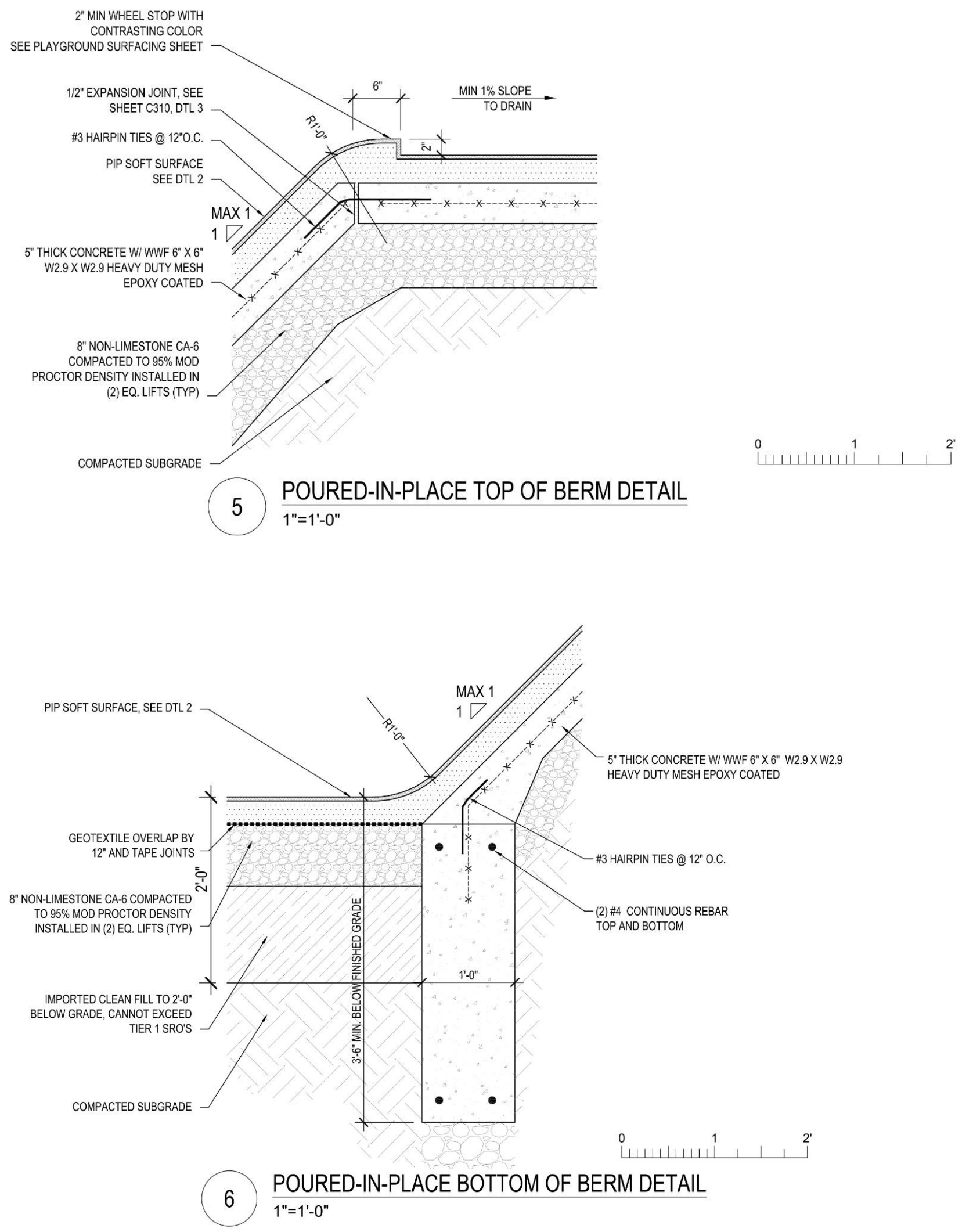

Mary Bartelme Park LPS Methodology Page 32 of 32 